\title{
Examining Metaphors, Usage and Views of Secondary School Students on YouTube
}

\author{
Aslıhan Saban \\ Necmettin Erbakan University, Turkey \\ ORCID: 0000-0002-8529-046X
}

Received: 23 Sep 2019

Accepted: 16 Oct 2019

Published: 14 Nov 2019

\begin{abstract}
YouTube is one of the social media tools that have become a part of our lives. It is used by many educators as a pedagogical instrument. To determine the perceptions and views students about YouTube can support the effective use of YouTube. For this purpose, metaphors and opinions of secondary school students about YouTube were tried to be determined. In this study, a phenomenological study have been used. Students' expressions about metaphors and their reasons were coded with free coding and then categories and themes were created. Also, questionnaires were analyzed according to frequency. According to the research results, YouTube has been associated with a technological tool at the highest frequency. In reasons part, YouTube is shown as "everything" at most. Students often use YouTube. YouTube channels related to daily life, online games and entertainment are more followed. Participants want to use YouTube for educational purposes. Few students want to be YouTuber. Many families do not control the time and content of their children on YouTube. School and teacher need to be able to develop activities regarding effective usage of YouTube in the pedagogical context. Besides this, all partners should be informed and participate in training for digital harmony.
\end{abstract}

Keywords: YouTube, metaphors, secondary school students

\section{INTRODUCTION}

Every new technological development that enters our lives somehow affects our lives. With the spread of the internet, our learning habits and daily routines have changed dramatically. For example, after waking up in the morning, behaviors such as checking news and messages from our mobile devices, looking at weather conditions or checking the status of incoming messages in WhatsApp applications have become routines in our lives. Our learning resources have changed and now newly introduced electronic resources are our first reference sources.

However, all these changes were already available in terms of young people and children who were considered digital natives. So that, it is appreciated normal and necessary for them to use Internet-based tools as essential part of their lives. As educators, identifying their perspectives on these tools in their world will shed light on their understanding and help in achieving educational objectives.

\section{SOCIAL MEDIA}

Web 2.0 can be defined as virtual environments where users can share content, intervene in content and receive feedback (Bat, 2012). With the development of Web 2.0 technologies, 
various internet environments have been started to be employed. Social networking sites, one of the most popular content sharing environments, are an important component of Web 2.0 technology (Karal \& Kokoç, 2010). Social media is defined as Web-based environments that enhance interpersonal interaction, support inter-individual sharing with common interests, as well as give everyone the chance to create their profile and the list of friends they want to communicate with (Vural \& Bat, 2010).

Social media applications can be grouped under the following categories; (a) Collaborative projects (Wikipedia etc.), (b) Blogs and microblogs (Wordpress.com, Blogger.com, etc.), (c) Content communities (YouTube, Flickr, SlideShare, etc.), (d) Social networking sites (Facebook, Instagram, etc.) , (e) Virtual game worlds (Minecraft, World of Warcraft, etc.) and (f) Virtual communities (Second Life etc.) (Kaplan \& Haenlein, 2010).

Various research has shown that, regardless of whether they live in the city center or rural area, students meet and use some social media tools at an early age (Batman, 2014). Adolescents spend most of their time on social media networks and these networks have become a part of their daily lives (Otrar \& Argın, 2014). Studies on the impact of social media on students were conducted. For example, in the studies (Al-Bahrani, Patel, \& Sheridan, 2015), it is emphasized that social media tools have an effective role in motivation and learning of students.

\section{YouTube}

With over 1.9 billion users worldwide, YouTube is the second social media tool after Facebook (www.wearesocial.com, 2019). YouTube is a social media tool where people can share their videos. YouTube defines its mission as giving everyone a voice and a chance to know the World (YouTube, 2019). YouTube, visited by millions of people daily, is currently owned by Google. Most of the contents are entertainment videos, but educational content is also available (Fleck, Beckman, Sterns, \& Hussey, 2014).

YouTube is a video-sharing website that allows users to upload, share and watch videos (Alwehaibi, 2015; Weinberg, 2009, p. 290). In addition to uploading personal videos, YouTube allows users to upload various types of video footage, such as movies, series of clips, documentaries, interviews, T.V. programs, or even slides, that other users may want to watch. In its most basic form, YouTube allows its users to upload and watch videos, and interact with other users (Özkonuk, 2019, p. 61).

Users can create their own channels within the video sharing sites and group the video lists by customizing these channels. Having the opportunity to comment on published videos allows users to comment on the videos they watch or post. As internet connection speeds increase, video sharing sites offer users the ability to view and upload high-definition videos (Elçiçek \& Bahçeci, 2015).

YouTuber is a person who produces content on YouTube to earn money or for fame. YouTubers promote shares information and advertises through the channels they actively create by sharing videos through YouTube (Özkonuk, 2019, p. 62). Becoming a YouTuber has quickly become a profession that brings fame and money (Sarıoğlu \& Özgen, 2018).

YouTubers often publish how-to videos, video blogs, game videos, funny videos, best videos, educational videos, box-opening videos, prank videos, make-up and fashionable videos on their channels according to their followers. As the number of viewers and followers grows and their videos and channels reach a certain popularity, they are no longer perceived as ordinary individuals, but they become famous (Özkonuk, 2019, p. 63). It is even stated that it is effective in the sales of some products with the broadcast of the YouTubers (Çalapkulu \& Şimşek, 2018). 


\section{YouTube in Education}

Researches related directing the students who spend most of their time in social networks to learn content have shown that video sharing sites increase students' learning motivations (Duffy, 2008; Elçiçek \& Bahçeci, 2015; Madden \& Lenhart, 2007). YouTube can be used for educational purposes in terms of both as a source and content produced by learners (VizcaínoVerdú, Contreras-Pulido, \& Guzmán-Franco, 2019). Video sharing platforms can help to create a structured classroom environment. Students can share their personal learning experiences by creating a video and the educators can use these videos to engage other students (Yeo, 2014).

The concept of Pedagogy 2.0 was introduced as a result of the opportunities offered by the social media and the choice of the learners within the framework of their learning wishes (McLoughlin \& Lee, 2007). Besides, YouTube raises the level of learning by commenting on the published videos and thus providing a discussion environment (Clifton \& Mann, 2011). Web 2.0 technologies provide users opportunities for interacting with each other and adding their own content. Further, web 3.0 will present content to users within the framework of their tendencies and wishes with the help of artificial intelligence. The pedagogical equivalent of this new situation is called pedagogy 3.0 (Gerstein, 2014).

YouTube can be used in many ways to improve and support the learning process (Alwehaibi, 2015). Duffy (2008) discusses the potential of video and visual resources to address multiple sensory sources with the use of YouTube in the learning process. Usage of YouTube as a teaching facilitator is particularly effective in knowledge construction and memory creation (BuzzettoMore, 2015).

YouTube is increasingly being used by educators as a pedagogical resource for especially in teaching English as a Second Language (Duffy, 2008). Vizcaino-Verdu and et al. (2019) focused on the potential of YouTube for reading and informal learning, and even mentions the concept of Booktubers for YouTubers who focus on reading and recommending books.

Another opportunity that YouTube provides is the potential of increasing interaction between the teacher and the student (Harley \& Fitzpatrick, 2009).

YouTube impacts education by providing free access to a huge volume of educational videos (Lee \& Lehto, 2013). YouTube EDU (http://www.youtube.com/edu) is a service for educators which contains short lessons from teachers, full university courses, professional development materials, and inspirational videos from global leaders. YouTube Teachers (https://www.youtube.com/user/teachers) service was created to help K-12 teachers use educational videos to educate, engage and inspire students with content aligned to common core standards. Finally, YouTube for Schools (https://www.youtube.com/schools) is an opt-in program that allows schools to access thousands of educational videos from vetted YouTube channels like PBS, TED, and Khan Academy in a secure environment (Buzzetto-More, 2015).

Besides all these positive contributions, there are some constraints in using YouTube in education. The main problem is the lack of quality control of user-generated content (Clifton \& Mann, 2011).

YouTube has been used in many courses in various educational levels (Alwehaibi, 2015; Duisembekova, 2014; Gül, 2015; Werner \& Frank, 2010);

- Elementary school vocabulary building (Duisembekova, 2014).

- Computer security training (Werner \& Frank, 2010)

- Nursing Education (Clifton \& Mann, 2011) 
- The use of high school students for academic purposes (Bardakcl, 2019)

- Moral and ego development (Koh, 2014)

- Psychology course at higher education (Jackman \& Roberts, 2014)

While watching videos on YouTube has become a daily habit for internet users (Majekodunmi \& Murnaghan, 2012), Aims of students using YouTube are also changing. For example; students use YouTube as an additional information source for preparing themselves for the real world better (Yeo, 2014).

Students spend the most of their daily life in social media. Secondary school students are more vulnerable to social and psychological influences. In addition, the foundations of professional choices were laid during this period. With these understandings, the opinions of the students about YouTube is important in the integration of YouTube in the learning processes. In this context, the research questions were determined as follows:

1- What are secondary school students' metaphors and the reasons of metaphors about YouTube?

2- What are the views of secondary schools' students about YouTube?

\section{METHOD}

\section{Research Model}

Although YouTube has a great place in the lives of middle school students who are considered as technology natives, there is no detailed information about their perceptions and metaphors about it. Because of this fact, the study was evaluated within the scope of the phenomenology.

Based on the work of the German philosopher Edmund Husserl, phenomenology has been developed as a theoretical framework and methodology to experience the experiences of individuals (Cilesiz, 2011). Studies employing phenomenology should be conducted with groups that can reflect the research phenomenon. A systematic way of data collection should be followed. The number of groups to be included in the sampling should be limited. The goal is to obtain a lot of useful data. In this kind of studies, data are typically collected through interviews. Observations may also be made in order to form the basis of the data (Yıldırım \& Şimşek, 2011). Phenomenology research should be built on a well-defined experience concept (Cilesiz, 2011).

A case-based approach is adopted in the analysis of data and the presentation of results. Also, findings can be presented comparatively. Due to the nature of this kind of research, results of the study may not generalize and may not be conclusive. However, examples and experiences are presented in a way that helps to define the phenomenon in question better and make it more understandable (Yıldııım \& Şimşek, 2011).

\section{Study Group}

The study group of this research consists of 134 secondary school students from Central Anatolian public schools in Turkey, 66 of 134 students were girls and 58 were boys. 10 of these students intentionally did not specify their gender. Participants are from different range of usage time of YouTube. So, participants have a maximum diversity in terms of gender, grade level and YouTube usage times. 


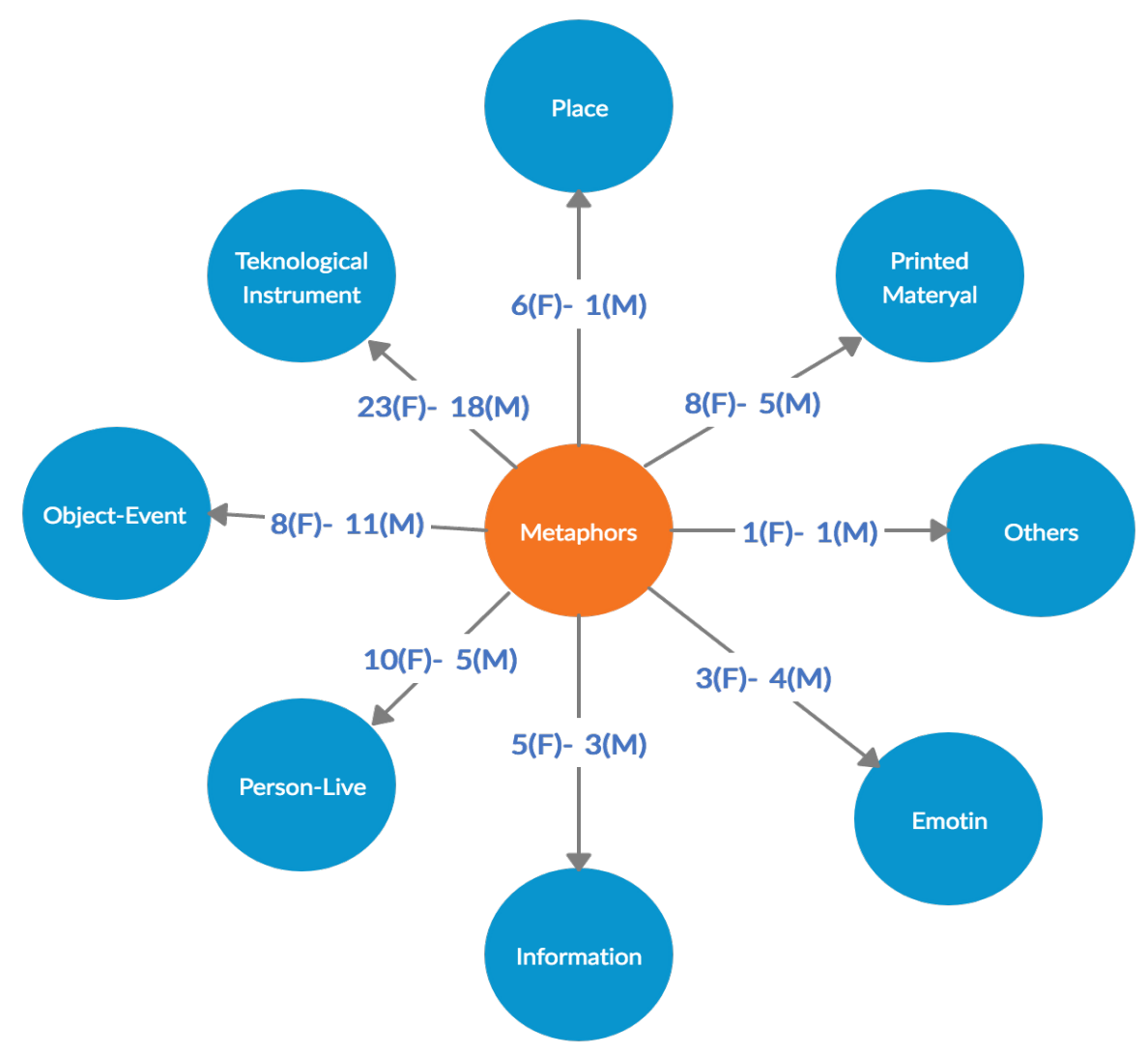

Figure 1. Concept map of metaphors and themes regarding YouTube

\section{Data Collection Tools}

For collecting data, two different instruments were employed in the study. In the Metaphor worksheet instrument, students are requested to fill in the blanks of the provided sentences like "YouTube is ............ because ...........". The second instrument was a questionnaire consisting of 10 questions which are used to determine the students' opinions about YouTube. Since the data collected via both instruments contained open-ended questions, they were analyzed qualitatively.

\section{DATA ANALYSIS}

In the first phase of the data analysis, the metaphors chosen by students for YouTube were determined. In second phrase, the reasons for using these metaphors were coded. The codes were then combined into categories and themes. To ensure coding reliability the codes identified were reviewed after a while. Coding reliability was calculated as $\% 92$ for the metaphor study and \%93 for the survey study. Survey data also calculated number of students in each choice. Then student answers were tabulated according to the questions.

\section{FINDINGS}

\section{Finding Related to Metaphors}

Metaphors expressed by students were categorized under certain themes. These themes are shown in Figure 1. 
Table 1. Distribution of Metaphors on the Theme of a Technological Instrument

\begin{tabular}{cccc}
\hline Metaphors & Female & Male & Total \\
\hline Television & 11 & 10 & 21 \\
\hline Computer & 3 & 1 & 4 \\
\hline Google & 3 & 1 & 4 \\
\hline Facebook & 2 & 0 & 2 \\
\hline Music Channel & 2 & 0 & 2 \\
\hline Movie Site & 0 & 1 & 1 \\
\hline Movie Or Game Watching & 0 & 1 & 1 \\
\hline Internet & 1 & 0 & 1 \\
\hline Music player & 0 & 1 & 1 \\
\hline Game Video Warehouse & 0 & 1 & 1 \\
\hline Robot & 0 & 1 & 1 \\
\hline Telephone & 0 & 1 & 1 \\
\hline Video and Music Listening Tool & 1 & 0 & $\mathbf{4 1}$
\end{tabular}

Table 2. Distribution of Metaphors on Object-Event and Person-Live Theme

\begin{tabular}{|c|c|c|c|}
\hline Metaphors & Female & Male & Total \\
\hline File & 1 & 2 & 3 \\
\hline Brain & 2 & 0 & 2 \\
\hline Empty box & 0 & 2 & 2 \\
\hline Theater & 1 & 1 & 2 \\
\hline Time Machine & 2 & 0 & 2 \\
\hline Key & 1 & 0 & 1 \\
\hline Bag & 0 & 1 & 1 \\
\hline Lesson & 0 & 1 & 1 \\
\hline Life & 0 & 1 & 1 \\
\hline Dream & 0 & 1 & 1 \\
\hline Hair dryer & 0 & 1 & 1 \\
\hline Cinema & 1 & 0 & 1 \\
\hline Water & 0 & 1 & 1 \\
\hline Total of Object-Event & 8 & 11 & 19 \\
\hline Teacher & 7 & 0 & 7 \\
\hline My friends & 2 & 1 & 3 \\
\hline Human & 0 & 2 & 2 \\
\hline A Smart Live & 0 & 1 & 1 \\
\hline A Thousand Eyes Live & 0 & 1 & 1 \\
\hline Walking Dead & 1 & 0 & 1 \\
\hline Total of Person-Live & 10 & 5 & 15 \\
\hline
\end{tabular}

In the metaphors expressed for YouTube, students mostly used analogy of technological tools. Details of each theme are presented in Table 1.

When the use of a TECHNOLOGICAL TOOL metaphor was examined, television metaphor has the highest frequency for both genders. Computer and Google metaphors were following it with the same frequencies. These two metaphors were mostly preferred by girls. Facebook, Internet, Video/Music listening tool and music channel metaphors are only expressed by girls. The other metaphors were expressed by male students.

When the OBJECT-EVENT theme is examined, file metaphor has the highest frequency. The empty box metaphor was preferred by men, while the brain and time machine metaphors were used only by girls. The other metaphors were used once. When the theme of PERSON-LIVE was examined, the teacher metaphor was the most frequently used metaphor. This metaphor was expressed only by girls. My friends metaphor was the second most frequently expressed 
Table 3. Distribution of Metaphors on Printed Material and Information

\begin{tabular}{cccc}
\hline Metaphors & Female & Male & Total \\
\hline Book & 3 & 4 & 7 \\
\hline Encyclopedia & 4 & 0 & 4 \\
\hline Magazine & 1 & 0 & 1 \\
\hline Newspapers & 0 & 1 & 1 \\
\hline Total of Printed Material & $\mathbf{8}$ & $\mathbf{5}$ & $\mathbf{1 3}$ \\
\hline Source of Information & 0 & 3 & 3 \\
\hline Information & 1 & 0 & 1 \\
\hline Information Monster & 1 & 0 & 1 \\
\hline Information Store & 1 & 0 & 1 \\
\hline Information Machine & 1 & 0 & 1 \\
\hline Information Fruit & 1 & 0 & 1 \\
\hline Total of Information & $\mathbf{5}$ & $\mathbf{3}$ & $\mathbf{8}$ \\
\hline
\end{tabular}

Table 4. Distribution of Metaphors on Places, Emotion and Others

\begin{tabular}{cccc}
\hline Metaphors & Female & Male & Total \\
\hline World & 3 & 0 & 3 \\
\hline Fun Fair & 1 & 0 & 1 \\
\hline Market & 1 & 0 & 1 \\
\hline Forest & 1 & 0 & 1 \\
\hline Play Ground & 0 & 1 & 1 \\
\hline Total of Places & $\mathbf{6}$ & $\mathbf{1}$ & $\mathbf{7}$ \\
\hline Funny & 2 & 1 & 3 \\
\hline Entertainment World & 0 & 2 & 2 \\
\hline Entertainment channel & 1 & 0 & 1 \\
\hline Have Fun and Wikipedia & 0 & 1 & 1 \\
\hline Total of Emotions & $\mathbf{3}$ & $\mathbf{7}$ & 1 \\
\hline Something Different & 1 & 0 & 1 \\
\hline Something Unlike Any Grip & 0 & 1 & $\mathbf{2}$ \\
\hline Total of Others & $\mathbf{1}$ & $\mathbf{1}$ &
\end{tabular}

metaphor in this theme. While male students used human, smart live and thousand eyes live metaphors, girls used walking dead metaphor with the lowest frequencies.

When the theme of PRINTED MATERIAL is examined, the most frequently used one was the book metaphor. This metaphor is expressed by both girls and boys. Expressed only by the girls, the metaphor of the encyclopedia follows it. Besides, magazine and newspaper metaphors were used rarely as well.

When the relationship with INFORMATION is examined, YouTube is seen as an information source by students. This metaphor is used only by boys. Information, information monster, information store, information machine and information fruit metaphors are expressed once and, only by girls.

World metaphor is seen as the most frequently used metaphor in this theme, when the theme of association with PLACE is examined, is $(\mathrm{N}=3)$. This metaphor was expressed only by girls. Funfair, market and forest metaphors were also expressed with low frequency by the girls $(\mathrm{N}=1)$. Playground metaphor was the single one expressed by boys in this theme with low frequency $(\mathrm{N}=1)$. When the theme of associating with EMOTION theme was examined, metaphors related to entertaining were the most frequently used metaphors. The entertainment world metaphor was expressed only by men. When the theme of others is examined, it is associated with the metaphor of something different and nothing similar to any concept. 


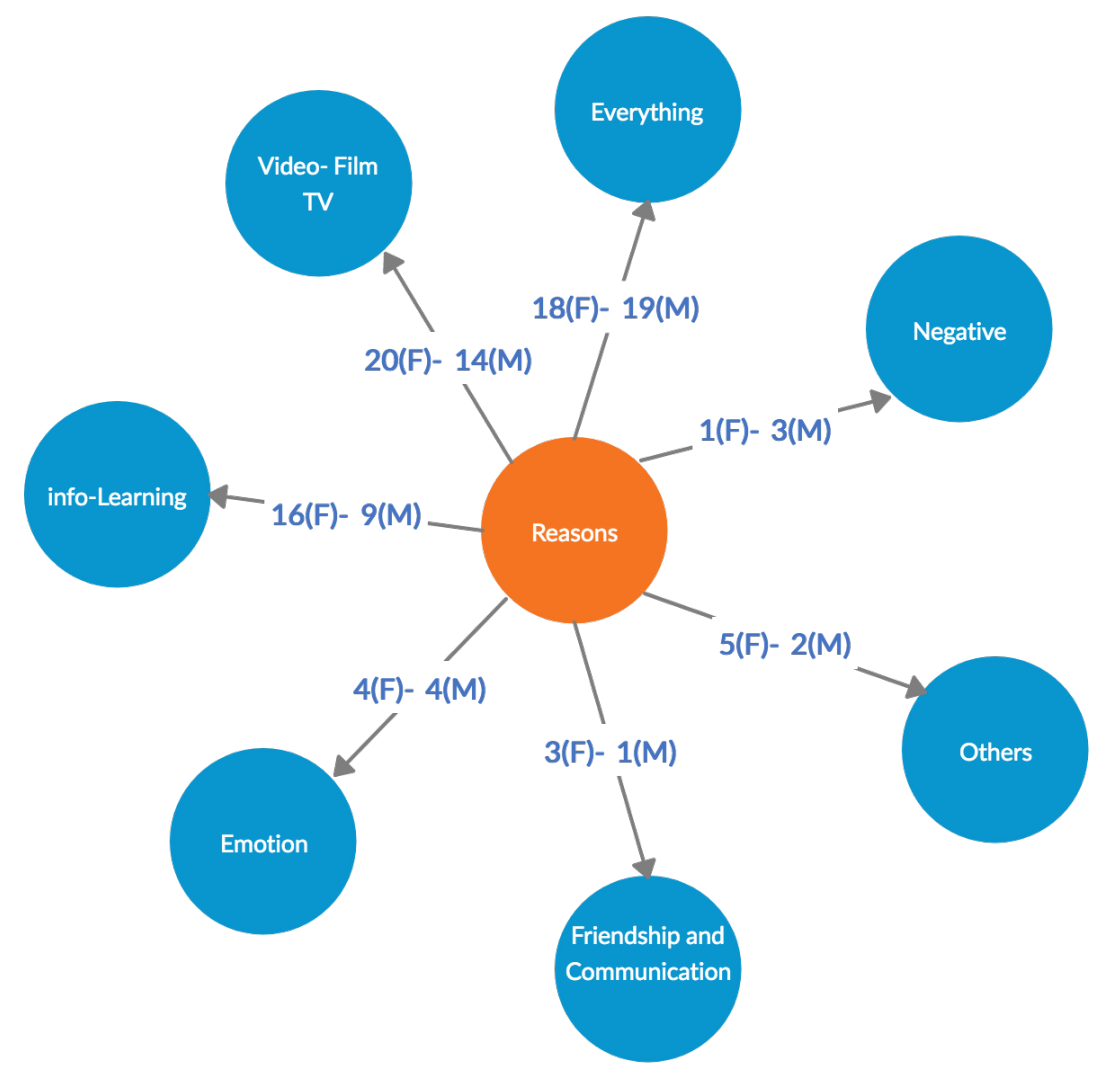

Figure 2. Concept Maps Regarding to Reasons of YouTube Metaphors

Table 5. Distribution of Reasons on Everything Theme

\begin{tabular}{cccc}
\hline Code & Female & Male & Total \\
\hline Everything has to happen & 9 & 8 & 17 \\
\hline Find everything that is wanted & 6 & 7 & 13 \\
\hline Each video has & 3 & 2 & 5 \\
\hline Everything in his hands & 0 & 1 & 1 \\
\hline You can do everything. & 0 & 1 & 1 \\
\hline Total & 18 & 19 & 37 \\
\hline
\end{tabular}

\section{Findings on the Reasons}

As for the themes related to the reasons in the metaphors, they expressed the code of "EVERYTHING" was the most frequently used code by the students. The codes with the lowest frequencies were "FRIENDSHIP-COMMUNICATION" and "negative contact" codes. When we sorted the rest of the codes by decreasing frequency, the order was as follows: VIDEO-FILM-TV, INFORMATION-LEARNING, EMOTIONAL, and other contacts.

When the theme of EVERYTHING is examined closely in terms of codes involved, everything happens and everything found codes stands out. It is outstanding that students have seen YouTube as everything. 
Table 6. Distribution of Reasons on Video- Film TV and info-Learning

\begin{tabular}{cccc}
\hline Codes & Female & Male & Total \\
\hline Watching Film-Video & 5 & 3 & 8 \\
\hline Videos & 3 & 2 & 5 \\
\hline All Movies Have & 3 & 1 & 4 \\
\hline All Types of Videos & 1 & 3 & 4 \\
\hline Music Channel & 2 & 1 & 3 \\
\hline There Are Most Things That Happen on Television & 2 & 1 & 3 \\
\hline There Are Documentaries & 2 & 0 & 2 \\
\hline There Are A Lot of Game Videos. & 1 & 1 & 2 \\
\hline Live Lifeless Beings Play. & 0 & 1 & 1 \\
\hline Traditional Things. & 1 & 0 & 1 \\
\hline Game Program. & 0 & 1 & $\mathbf{3 4}$ \\
\hline Total of Video-Film-Tv & $\mathbf{2 0}$ & $\mathbf{1 4}$ & 9 \\
\hline Information source & 4 & 5 & 5 \\
\hline showing any information & 5 & 0 & 4 \\
\hline Don't tell us about it & 3 & 1 & 2 \\
\hline Teaching knowledge & 3 & 0 & 1 \\
\hline learning something & 1 & 1 & 1 \\
\hline Contributing to education & 0 & 1 & $\mathbf{2 5}$
\end{tabular}

Table 7. Distribution of Reasons on Emotion, Friendship and Communication

\begin{tabular}{cccc}
\hline Codes & Female & Male & Total \\
\hline Fun & 3 & 2 & 5 \\
\hline Funny & 1 & 1 & 2 \\
\hline Weeping & 0 & 1 & 1 \\
\hline Total of Emotion & $\mathbf{4}$ & $\mathbf{4}$ & $\mathbf{8}$ \\
\hline It Open What We Type & 2 & 0 & 2 \\
\hline There Are Many Files & 0 & 1 & 1 \\
\hline Not Alive & 1 & 0 & 1 \\
\hline Doesn't Look Like an Inanimate Being & 1 & 0 & 1 \\
\hline Something Different & 1 & 0 & 1 \\
\hline It Is Not Like Anything. & 0 & 1 & 1 \\
\hline Associating with Market Sections & 1 & 0 & 1 \\
\hline Total of Others & $\mathbf{5}$ & $\mathbf{7}$ & $\mathbf{4}$ \\
\hline Friendship-Communication & $\mathbf{3}$ & $\mathbf{2}$ & 2 \\
\hline Taking Time & 0 & 2 & 1 \\
\hline It Is Very Complicated & 1 & 0 & $\mathbf{4}$ \\
\hline Making Too Much Noise & 0 & 1 & $\mathbf{3}$ \\
\hline Total of Negative & $\mathbf{1}$ & &
\end{tabular}

When the video film theme is examined, watching movies-videos, finding videos, having all films and the existence of all kinds of videos codes come to the forefront. In the theme of knowledge and learning, students code stands out with YouTube information source, showing every information and narrative themes. In this theme, girls contributed more to other codes than the source of the information.

In the EMOTIONAL theme, entertaining, funny and weeping codes were expressed. In this category, boys and girls produced an equal number of codes. Codes that does not fit into any other theme were collected under others theme. In the theme of FRIENDSHIPCOMMUNICATION, the statements expressed by students were collected under a single code. In this theme, the girls produced more codes than boys did. Under the theme of negative, the negative reasons of the participants were collected. In this theme, it is stated that it takes time, 
Table 8. Spending time on YouTube

\begin{tabular}{ccccc}
\hline & Female & Male & Total \\
\hline $0-1$ & 40 & 42 & 82 \\
\hline $1-3$ & 20 & 12 & 32 \\
\hline $3-5$ & 5 & 2 & 7 \\
\hline $5 \mathrm{ve}+$ & 0 & 2 & 2 \\
\hline
\end{tabular}

Table 9. Attitudes of Families Towards Their Children's Spending Time on YouTube

\begin{tabular}{cccc}
\hline & Female & Male & Total \\
\hline Understanding And Acceptance & 22 & 14 & 36 \\
\hline Warning & 7 & 10 & 17 \\
\hline No using & 9 & 5 & 14 \\
\hline Be Angry & 7 & 6 & 13 \\
\hline Ask \& Control & 10 & 3 & 13 \\
\hline Unresponsiveness \& Apathy & 4 & 7 & 11 \\
\hline
\end{tabular}

Table 10. Classification of YouTube Channels followed by Students

\begin{tabular}{cccc}
\hline Classification & Female & Male & Total \\
\hline Daily Life video & 47 & 73 & 120 \\
\hline Online game introduction & 32 & 46 & 77 \\
\hline Game and adventure videos & 24 & 20 & 44 \\
\hline Practical information & 20 & 14 & 34 \\
\hline Introduction of technological tools & 0 & 12 & 12 \\
\hline YouTube commentator & 6 & 5 & 11 \\
\hline TV channel & 5 & 2 & 7 \\
\hline Cartoon & 6 & 0 & 6 \\
\hline Training Videos & 1 & 4 & 5 \\
\hline Soap opera & 3 & 0 & 2 \\
\hline Tool making & 2 & 0 & 2 \\
\hline Other & 2 & 0 & 1 \\
\hline Kid games & 1 & 0 & 1 \\
\hline Football Match videos & 0 & 1 & 1 \\
\hline Music channel & 0 & 1 & 1
\end{tabular}

it is very complicated, and it makes a lot of sounds. In this category, male students produced more codes than female students.

\section{Findings Related Survey}

YouTube usage rates of students are shown in Table 8. The majority of the participant students $(\mathrm{N}=82)$ are using YouTube " $0-1$ hours" daily, 32 participants stated that they are using YouTube "1-3 hours" in a typical day. The rest of the participants stated that they are using YouTube "3 or more hours" on a daily basis.

According to the participants, a significant portion of families $(\mathrm{N}=36)$ shows "understanding and acceptance" for the time their children spend on YouTube. A comparatively low number $(N=17)$ of families have warned their kids, or expressed anger $(N=13)$ and asked control $(N=13)$ for the time participants spent on YouTube. 17 students stated that they are not using YouTube regularly. Relatively few numbers of families $(\mathrm{N}=11)$ were unresponsive and uninterested in internet usages of their kids.

YouTube channels that students stated they follow are classified according to the content they provide. Frequency distribution of classified channels is shown in Table 10. In general, YouTube channels broadcasting daily life videos, games and entertainment content are more preferred 
Table 11. The kinds of videos watched by participant on YouTube

\begin{tabular}{cccc}
\hline & Female & Male & Total \\
\hline Educational videos & 40 & 29 & 69 \\
\hline Entertainment videos & 34 & 29 & 63 \\
\hline Clips, music & 35 & 25 & 60 \\
\hline Game videos & 24 & 33 & 57 \\
\hline Short movies & 26 & 27 & 53 \\
\hline
\end{tabular}

Table 12. Willingness to become a YouTuber

\begin{tabular}{cccc}
\hline & Female & Male & Total \\
\hline No & 50 & 34 & 84 \\
\hline Yes & 14 & 24 & 38 \\
\hline Explanation about No & 34 & 13 & 47 \\
\hline Other profession & 8 & 2 & 10 \\
\hline Unwillingness & 9 & 1 & 10 \\
\hline Lack of interest & 5 & 3 & 8 \\
\hline Difficult & 5 & 1 & 6 \\
\hline Boring & 4 & 0 & 4 \\
\hline No Knowledge & 1 & 1 & 2 \\
\hline Unnecessary & 0 & 2 & 1 \\
\hline Harmful & 0 & 2 & 1 \\
\hline Family not to let & 1 & 0 & 1 \\
\hline Excitability & 1 & 0 & 33 \\
\hline Only hobby & 0 & 1 & 16 \\
\hline Explanation about Yes & 13 & 7 \\
\hline Funny & 8 & 20 & 6 \\
\hline Earning money & 2 & 8 & 4 \\
\hline Giving information & 3 & 5 & 1 \\
\hline Becoming famous & 1 & 3 & 1 \\
\hline Liking & 0 & 3 & 1 \\
\hline Wonder & 0 & 2 & 1 \\
\hline Be happy & 0 & 1 & 2 \\
\hline I'm already doing & 0 & 1 & 2 \\
\hline
\end{tabular}

by the students. Whereas, YouTube channels broadcasting informative and educational content are less preferred.

Activities of students on YouTube are shown in Table 11. According to the table, watching educational videos is the most frequently expressed activity $(\mathrm{N}=69)$, followed by entertainment videos $(N=63)$, clips and music $(N=60)$, game videos $(N=57)$ and short films $(N=53)$. It is seen that male students mainly prefer game videos and short movies while female students prefer educational and entertainment videos.

When the situation of willingness to become a Youtuber as a profession was examined, it is seen the fact that the majority of the participants $(\mathrm{N}=84)$ did not want to be a YouTuber. Majority of those willing to be a YouTuber were boys $(\mathrm{N}=24)$. Those who don't want to be a YouTuber stated that they desired other professions or they were not interested. Some of the participants affirmed that being a YouTuber was boring $(\mathrm{N}=4)$, difficult $(\mathrm{N}=6)$, harmful $(\mathrm{N}=2)$ and unnecessary $(\mathrm{N}=2)$. , Having some fun $(\mathrm{N}=16)$, earning money $(\mathrm{N}=7)$, sharing information $(\mathrm{N}=6)$ and being famous $(\mathrm{N}=4)$ were prominent reasons for those who wish to be YouTuber. One of the male students expressed that he was already a YouTuber. 
Table 13. Making friends via YouTube

\begin{tabular}{cccc}
\hline & Female & Male & Total \\
\hline No & 58 & 51 & 109 \\
\hline Yes & 7 & 7 & 14 \\
\hline Explanation about Yes & 6 & 4 & 10 \\
\hline Harmless & 4 & 4 & 8 \\
\hline My friends in real life & 2 & 0 & 2 \\
\hline unwillingness & 32 & 27 & 59 \\
\hline can deceive & 11 & 11 & 22 \\
\hline Detrimental & 5 & 6 & 11 \\
\hline distrust & 5 & 5 & 10 \\
\hline He could be a bad guy & 4 & 4 & 8 \\
\hline adversely affect success & 2 & 1 & 3 \\
\hline t drives us away from society. & 2 & 0 & 1 \\
\hline it's strange to meet & 0 & 1 & 1 \\
\hline we can be addicted to YouTube & 1 & 0 & 1 \\
\hline Share my information & 1 & 0 & 1 \\
\hline harmless & 1 & 0 & 1 \\
\hline
\end{tabular}

Table 14. Contribution of YouTube Videos to Lessons

\begin{tabular}{cccc}
\hline & Female & Male & Total \\
\hline Yes & 56 & 37 & 93 \\
\hline No & 10 & 19 & 29 \\
\hline Explanation about Yes & 43 & 25 & 68 \\
\hline Learning the subject that they do not understand & 11 & 5 & 16 \\
\hline Getting information & 7 & 7 & 14 \\
\hline Course Video & 7 & 5 & 12 \\
\hline Better learning & 6 & 3 & 9 \\
\hline Course Support & 4 & 2 & 6 \\
\hline Research and homework & 2 & 1 & 3 \\
\hline Partial support & 3 & 0 & 3 \\
\hline Good in teaching & 1 & 1 & 2 \\
\hline Different thinking skills & 1 & 1 & 1 \\
\hline Learning foreign languages & 1 & 0 & 10 \\
\hline Explanation about No & 4 & 6 & 5 \\
\hline Watching extra-curricular & 3 & 2 & 3 \\
\hline No contribution & 0 & 3 & 1 \\
\hline If we watch informative videos. & 1 & 0 & 1 \\
\hline Not using & 0 & 1 & \\
\hline
\end{tabular}

As for making friends on YouTube, the majority of students $(\mathrm{N}=109)$ answered that they don't make any friends on YouTube and only 14 students said they do. Those who make friends on YouTube think that it is not harmful or they are already friends in their real life. Those who don't make friends explained their behavior with a lack of will, fear of deceit, and lack of trust. They also think that their success would be affected negatively.

Table 14 shows the opinions of participants regarding possible contributions of YouTube to their academic life. The majority of students articulated that watching videos on YouTube contributed positively to their lessons ( $\mathrm{N}=93$ ). While explaining their thoughts, "Learning the subject that they do not understand", "Getting information" and "Course Video" are prominent. Also, "Better learning", "Course Support", "Research and homework" and "Partial support" are also mentioned. Students who think watching videos on YouTube do not contribute to their academic life stated that they are "Watching extra-curricular" videos $(\mathrm{N}=5)$ or they think YouTube videos have "No contribution" to their lessons $(\mathrm{N}=3)$. 
Table 15. Usage of YouTube for Educational Purposes

\begin{tabular}{cccc}
\hline & Female & Male & Total \\
\hline Yes & 60 & 48 & 108 \\
\hline No & 5 & 9 & 14 \\
\hline Explanation about Yes & 47 & 25 & 72 \\
\hline Supplementary course material & 15 & 6 & 21 \\
\hline Knowledge acquisition \& learning & 6 & 6 & 12 \\
\hline It'll be helpful & 7 & 4 & 11 \\
\hline Contribution & 7 & 2 & 9 \\
\hline Being more successful & 5 & 0 & 5 \\
\hline Learning with fun & 2 & 2 & 4 \\
\hline Easy learning & 2 & 2 & 4 \\
\hline education develops & 3 & 0 & 3 \\
\hline educational purpose & 0 & 2 & 2 \\
\hline Ga interested with educational videos & 0 & 1 & 1 \\
\hline Explanation about No & 1 & 0 & 1 \\
\hline
\end{tabular}

Table 16. Effects of watching videos on YouTube

\begin{tabular}{cccc}
\hline & Female & Male & Total \\
\hline Helped my lessons - my education & 52 & 37 & 89 \\
\hline It made me recognize different cultures. & 33 & 25 & 68 \\
\hline It improved my foreign language. & 16 & 20 & 36 \\
\hline It made me friends. & 6 & 9 & 15 \\
\hline Explanation & 23 & 15 & 38 \\
\hline
\end{tabular}

Table 17. Disturbing Related YouTube videos

\begin{tabular}{cccc}
\hline & Female & Male & Total \\
\hline Advertisements & 38 & 36 & 74 \\
\hline Inappropriate videos for their ages & 34 & 16 & 50 \\
\hline Obscenity & 19 & 25 & 44 \\
\hline Abusive insiders & 1 & 3 & 4 \\
\hline Explanation & 2 & 1 & 3 \\
\hline The emergence of irrelevant things & 28 & 23 & 51 \\
\hline
\end{tabular}

Table 15 shows the usage purposes of YouTube by participants. According to the table the majority of students ( $\mathrm{N}=108)$ are using YouTube for educational purposes. Students are using YouTube videos as "Supplementary material for courses they take", for "Acquisition \& learning of new knowledge ". They also think YouTube videos will "Help" and "Contribute" to their lessons and academic success. According to the table above, a substantial proportion of students $(\mathrm{N}=14)$ think watching YouTube videos may affect their academic success negatively.

Table 16 shows the general effects of watching videos on YouTube. Participant students think YouTube videos helped "academic success in their lessons" ( $N=89)$, "them recognize different cultures" ( $N=68)$ and "to improve their foreign language skills" $(\mathrm{N}=36)$. They also think YouTube helped them making friends $(\mathrm{N}=15)$.

Majority of participant students $(\mathrm{N}=74)$ stated they found disturbing "the ads about what they were upset about". They are also uncomfortable with the inappropriate videos for their age $(\mathrm{N}=50)$. Exposure to obscenity is the third cause of discomfort for students $(\mathrm{N}=44)$. Abusive insiders and irrelevant videos are other causes of discomfort. 


\section{RESULTS AND DISCUSSIONS}

Aim of this study was to find out the metaphors of students regarding YouTube. In accordance with this aim, phenomenological research carried out to discover metaphors of students and metaphors expressed by students were categorized under 7 themes, namely Technological Tools, Places, Printed Material, Object-Event, Knowledge, Emotion, and Others. Results of the study showed that the metaphors of the participant students were mostly related to technological tools, object-events, person-living, and printed materials. Television was the most frequently used metaphor in technological tool theme, file metaphor was the most often used metaphor object-event theme. Teacher metaphor was the most frequently used metaphor in the theme of people-live, while the book metaphor was most often used in the printed materials. Further semantic analysis of the themes surfaced suggests that students identify YouTube with television as a technological tool. They also identify YouTube with a teacher when they are asked to compare it with a person in their life. They consider YouTube as a book, and a world in which everything can be found, and an information source for learning.

In Köseoğlu's study (2017), which investigated the metaphors about social media, the technology that facilitates life, education, information, entertainment, and danger concepts are associated with life. In our study, it is seen that similar groupings occur in metaphors related to YouTube. For example, participants in both study use metaphors such as "source of information", "instrument of entertainment", "technological tools". In the study conducted by Fleck et al. (2014), participants were asked to mark the adjectives that define YouTube. In the study, students preferred positive adjectives (Fun, Helpful, Beneficial for learning, Engaging, Entertaining) and negative adjectives (Annoying, Distracting, Waste of time, A time to nap, Irrelevant to course material). Besides this, these participants are defined as technology natives by Prensky (2001). The fact that the majority of metaphors are related to technology confirms this analogy.

When the reasons are examined, everything, video-film-tv and information-learning themes come to the fore. While "Everything has to happen" and "Find everything that is wanted" statements come to the forefront in the theme of everything, "Watching Film-Video" and "Videos" come to the fore in video-film-tv theme. In addition, "source of information" and "showing any information" are more expressed in the information-learning theme. Despite this, a small number of negative statements have been expressed such as, "Making too much noise" and "Taking Time". The fact that students use the reasons like "Everything has to happen" and "Find everything that is wanted" shows that they trust the content they get on YouTube in a sense.

According to another finding of this study, the main difficulties in using YouTube for informational purposes were the accuracy and quality of the videos on YouTube. For example, in a study conducted by Adhikari et al. (2016) about cervical cancer videos on YouTube has shown that videos broadcasting actual videos were more popular than videos describing people's verbal experiences. Results of the study also revealed that although there were some videos prepared by the professionals, the number of videos was low.

As for the survey data, the majority of the participant students were using YouTube between 01 hours daily. Considering that they are in the school period, the proportion of students using 1 hour or more is considerably high. Vural and Bat (2010) reported that students spend 1-3 hours in social media applications per day, while Balaman and Karataş (2012) found that students spend 1-2 hours per day on social media. Although the time of internet usage by students reported in other studies includes all social media applications, it can give an idea about YouTube usage also. In the study conducted by Bedir (2016), the rate of university students usage 
photo/video sharing platforms was $88.3 \%$. These findings suggest that YouTube has a place in the daily lives of students. So, social media should be integrated to the education system and students should be educated effectively about the usage of social media

When YouTube channels followed by participant students are examined, channels that contain videos about personal life, online game recordings, game, and adventure videos, and practical information were most often followed ones. The students stated that they watched educational and entertainment videos more than other types of videos. According to Sarı and Özgen (2018) while male students are more interested in football, gaming, and technology; for female students, communication with friends, fashion, health and makeup trends take the first place.

When asked whether YouTube contributed to their lessons, the majority of students replied that it has positive contributions. Students stated that they utilized YouTube for learning about the subjects that they did not understand, for obtaining information and for watching related lesson videos. Students who reported that they did not use YouTube for educational purposes stated that they were watching extracurricular videos. When asked if they want to use YouTube for educational purposes, the majority of students stated that they want to. Students expressed "auxiliary materials to courses", "knowledge-learning", "being useful" and "contributing" as a rationale. According to Tonta (2009), even the concept of the library has changed for this group of students who are considered as digital natives. In this case, the possibilities of social media should also be used for education. The importance of digital literacy is foreground. It is accepted that digital literacy skills are related to 21 . century skills (van Laar, van Deursen, van Dijk, \& de Haan, 2017) (Van Laar, 2017) and critical skills for their future life (Neumann, Finger, \& Neumann, 2017).

The study reveals a dilemma when YouTube channels were followed by students and students' desire to use YouTube for educational purposes are investigated together. Students want to use YouTube for educational purposes, but in reality, they don't use much. This may be perceived as a "digital dissonance" (Atal \& Usluel, 2011) when the frequency of educational use and the YouTube channel followed by the students are considered together. The term "digital dissonance" was used by Clark et al (2009) to express the differentiation of social media usage of 11-16-year-old students inside and outside the school. According to Clark et al (2009) not only learners but also their teachers and institutions are experiencing a sense of dissonance around learners' in- and out-of-school uses of Web 2.0 technology and related devices. If Web 2.0 activities (for example YouTube) are to be integrated usefully across formal and informal learning, teachers, learners, and institutions need to develop shared strategies and understandings approach to technology use in schools. They need to be able to consider and explore the benefits of technology-mediated collaborative practice rather than school mediated regulation of technology use.

The study also showed that the majority of participant students do not prefer being a Youtuber as a professional. As an explanation, they were either not interested in YouTube or want another profession. Those who want to be Youtuber think that being a Youtuber might be fun and help them make money. Participant students also think that YouTube videos contribute to their lessons, helps to recognize different cultures and improves their foreign language skills. According to (Sarıoğlu \& Özgen, 2018) Generation Z prefers to blend learning with entertainment. Right adaptation of the humor factor may play a key role in attracting them.

According to the results of the study families of the students showed a positive attitude towards YouTube usage of their kids. But they also have criticism and want to control/limit the usage of YouTube. Some parents were either unresponsive or unrelated to their kids YouTube usage. As for making friends on YouTube, the majority of students were reluctant. The major causes of 
this situation were the fear of being tricked and damaged. Some students think it's not harmful making friends on YouTube because they only make friends with the other people they already know. Students find the appearance of ads, lack of age-appropriate content and obscenity disturbing. Another disturbing factor was the parents' control of YouTube usage. Some of the students stated that some ads and contents are inappropriate. The research revealed many families do not control what their children watch on YouTube. The study conducted by Buzzi (2012), showed that only $1 / 3$ of the parents were controlling the YouTube channels their kids were watching.

Results of the study showed YouTube has become a part of the daily lives of students who are considered technology natives. However, they also want to use it for educational purposes.

\section{RECOMMENDATIONS}

Social media tools like YouTube are inevitable in the lives of students and they should be transformed into pedagogical opportunities and adapted to the education system with effective guidance both inside and outside the school. It is recommended to use these social media tools beside classical teaching tools and techniques. In this study usage and opinions of secondary school students about YouTube were examined. Opportunities and possibilities were discussed to guide educators. YouTube can be turned into an educational and pedagogical tool by investigating deeper and gathering opinions of other educational stakeholders (parents, teachers, administrators). In addition, a detailed examination of the criteria used by students when watching videos and following channels on YouTube may help researchers in the field about increasing the effectiveness of videos and their uses in learning. School and teacher need to be able to consider and explore the benefits of technology-mediated collaborative practice rather than school mediated regulation of technology use. Besides this, all partners (teacher, students, families, school manager) should be informed and participate in training for digital harmony. The data obtained from the study is based on the students' statements. The limitation of this study is that YouTube usage information or parents' thoughts and behaviors are not expressed in the real setting or by the parents themselves. The fact that the data was collected from one school would create a restriction on the generalization of the study.

\section{REFERENCES}

Al-Bahrani, A., Patel, D., \& Sheridan, B. (2015). Engaging students using social media: The students' perspective. International Review of Economics Education, 19, 36-50. https://doi.org/10.1016/j.iree.2015.06.001

Alwehaibi, H. O. (2015). The Impact of Using YouTube in EFL Classroom on Enhancing EFL Students' Content Learning. Journal of College Teaching \& Learning (TLC), 12(2), 121. https://doi.org/10.19030/tlc.v12i2.9182

Atal, D., \& Usluel, Y. K. (2011). İlköğretim Öğrencilerinin Okul İçinde Ve Dışında Teknoloji Kullanımları [Elementary School Students' Use of Technology in And Out of School]. H. U. Journal of Education, (41), 24-35.

Bardakcı, S. (2019). Exploring High School Students' Educational Use of YouTube. The International Review of Research in Open and Distributed Learning, 20(2). https://doi.org/10.19173/irrodl.v20i2.4074 
Bat, M. (2012). Dijital platformda sosyal medyanın stratejik kurumsal iletişime etkisi [The effect of social media on strategic corporate communication in digital platform] (Unpublished Ph.D. Thesis). Ege Üniversitesi Sosyal Bilimler Enstitüsü.

Batman, M. (2014). Erzurum ili Örneğinde Illkokul Öğrencilerinin Sosyal Medya Farkındalığı Üzerine Bir Inceleme [A Study On The Social Media Awareness Of Primary School Students In The Sample Of Erzurum] (Unpublished M.A. Thesis). Atatürk Üniversitesi, Sosyal Bilimler Enstitüsü.

Bedir, A. (2016). Sosyal Medya Kullanımının Üniversite Öğrencilerinin Akademik Başarılarına Ve Tutumlarına Etkisi [The Effect of Using Social Media on Collage Academic Success and Attitude] (Unpublished M.A. Thesis). Atatürk Üniversitesi, Eğitim Bilimleri Enstitüsü.

Buzzetto-More, N. (2015). Student Attitudes towards the Integration of YouTube in Online, Hybrid, And Web-Assisted Courses: An Examination of the Impact of Course Modality on Perception. MERLOT Journal of Online Learning and Teaching, 11(1), 20.

Buzzi, M. (2012). What Are Your Children Watching on YouTube? In F. Cipolla-Ficarra, K. Veltman, D. Verber, M. Cipolla-Ficarra, \& F. Kammüller (Eds.). Advances in New Technologies, Interactive Interfaces and Communicability, 7547, 243-252. https://doi.org/10.1007/9783-642-34010-9_23

Çalapkulu, Ç., \& Şimşek, R. (2018). Sosyal Medyanın Reklam Aracı Olarak Kullanılmasında Youtube: Sakarya Üniversitesi Iletişim Fakültesinde Bir Araştırma [Youtube: A Research in Sakarya University Faculty of Communication]. International Journal of Social Science, 1(2), 269-278.

Cilesiz, S. (2011). A phenomenological approach to experiences with technology: Current state, promise, and future directions for research. Educational Technology Research and Development, 59(4), 487-510. https://doi.org/10.1007/s11423-010-9173-2

Clark, W., Logan, K., Luckin, R., Mee, A., \& Oliver, M. (2009). Beyond Web 2.0: Mapping the technology landscapes of young learners: Beyond Web 2.0. Journal of Computer Assisted Learning, 25(1), 56-69. https://doi.org/10.1111/j.1365-2729.2008.00305.x

Clifton, A., \& Mann, C. (2011). Can YouTube enhance student nurse learning? Nurse Education Today, 31(4), 311-313. https://doi.org/10.1016/j.nedt.2010.10.004

Duffy, P. (2008). Engaging the YouTube Google-Eyed Generation: Strategies for Using Web 2.0 in Teaching and Learning. Electronic Journal of e-Learning, 6(2), 12.

Duisembekova, Z. (2014). The Use of English Songs on YouTube to Teach Vocabulary to Young Learners (Unpublished M.A. Thesis). Gazi üniversitesi, Eğitim Bilimleri enstitüsü, Ankara.

Elçiçek, M., \& Bahçeci, F. (2015). Bilgisayar ve Öğretim Teknolojileri Eğitimi Bölümü Öğretmen Adaylarının Video Paylaşım Sitelerine İlişkin Görüşlerinin İncelenmesi [An Evaluation of Computer Education and Instructional Technologies Prospective Teachers' Opinions on Video Sharing Websites]. Journal of Social Sciences Institute, (3), 95-108.

Fleck, B. K. B., Beckman, L. M., Sterns, J. L., \& Hussey, H. D. (2014). YouTube in the Classroom: Helpful Tips and Student Perceptions. The Journal of Effective Teaching, 14, 17.

Gerstein, J. (2014). Moving from Education 1.0 through Education 2.0 towards Education 3.0. In L. M. Blaschke, C. Kenyon, \& S. Hase (Eds.), Experiences in Self-Determined Learning. 
Gül, E. (2015). Meslek Lisesi Öğrencilerinin Eğitiminde E-Öğrenme 2.0'ın Önemi (Merzifon Örneği) [The Significance Of E-Learning 2.0 On the Education of Vocational School Students (Merzifon Sample)] (Unpublished M.A. Thesis). Afyon Kocatepe Üniversitesi, Fen Bilimleri enstitüsü.

Harley, D., \& Fitzpatrick, G. (2009). Creating a conversational context through video blogging: A case study of Geriatric1927. Computers in Human Behavior, 25(3), 679-689. https://doi.org/10.1016/j.chb.2008.08.011

Jackman, W. M., \& Roberts, P. (2014). Students' Perspectives on YouTube Video Usage as an EResource in the University Classroom. Journal of Educational Technology Systems, 42(3), 273-296. https://doi.org/10.2190/ET.42.3.f

Kaplan, A. M., \& Haenlein, M. (2010). Users of the world, unite! The challenges and opportunities of Social Media. Business Horizons, 53(1), 59-68. https://doi.org/10.1016/j.bushor.2009.09.003

Karal, H., \& Kokoç, M. (2010). Üniversite Öğrencilerinin Sosyal Ağ Siteleri Kullanım Amaçlarını Belirlemeye Yönelik Bir Ölçek Geliştirme Çalışması [A Scale Development Study for Determining University Students' Purpose of Use of Social Networking Sites]. Turkish Journal of Computer and Mathematics Education, 1(3), 251-263.

Koh, C. (2014). Exploring the use of Web 2.0 technology to promote moral and psychosocial development: Can YouTube work?: Using YouTube to promote moral and psychosocial development. British Journal of Educational Technology, 45(4), 619-635. https://doi.org/10.1111/bjet.12071

Köseoğlu, P. (2017). An Analysis of Prospective Teachers' Perceptions Concerning the Concept of "Social Media" through Metaphors. Eurasia Journal of Mathematics, Science and Technology Education, 14(1), 45-52. https://doi.org/10.12973/ejmste/79325

Lee, D. Y., \& Lehto, M. R. (2013). User acceptance of YouTube for procedural learning: An extension of the Technology Acceptance Model. Computers \& Education, 61, 193-208. https://doi.org/10.1016/j.compedu.2012.10.001

Madden, M., \& Lenhart, A. (2007). Social networking websites and teens: An overview. Pew Internet Project Data Memo. Available at: http://Pewinternet.org/PPF/r/198/Report_ display.asp (Accessed March 10, 2008)

Majekodunmi, N., \& Murnaghan, K. (2012). "In Our Own Words": Creating Videos as Teaching and Learning Tools. Partnership: The Canadian Journal of Library and Information Practice and Research, 7(2). https://doi.org/10.21083/partnership.v7i2.2007

McLoughlin, C., \& Lee, M. (2007). Social software and participatory learning: Pedagogical choices with technology affordances in the Web 2.0 era. Ascilite 2007, "ICT: Providing Choices for Learners and Learning," 12.

Neumann, M. M., Finger, G., \& Neumann, D. L. (2017). A Conceptual Framework for Emergent Digital Literacy. Early Childhood Education Journal, 45(4), 471-479. https://doi.org/10.1007/s10643-016-0792-z

Otrar, M., \& Argın, F. S. (2014). Ergenlerin Sosyal Medyaya Iliş̧in Tutumlarının Çok Boyutlu Incelenmesi [Multidimensional Examination of the Adolescents' Attitude Concerning Social Media]. Journal of Education and Humanities: Theory and Practice, 5(10), 3-22. 
Özkonuk, B. (2019). Çocukluk Sosyolojisi Bağlamında Çocuk Özneler Için Youtube Ve Youtuber Olmak Üzerine Bir Inceleme [A Research on YouTube and Being a Youtuber for Child Subjects in Context of The Sociology of Childhood] (Unpublished M.A. Thesis). Aydın Adnan Menderes Üniversitesi, Sosyal Bilimler Enstitüsü, Aydın.

Prensky, M. (2001). Digital Natives, Digital Immigrants. On the Horizon, 15.

Sarıoğlu, E. B., \& Özgen, E. (2018). Z Kuşağının Sosyal Medya Kullanım Alışkanlıkları Üzerine Bir Çalışma [A Study of the Social Media Usage Habits of Generation Z]. Journal of International Social Research, 11(60), 1067-1081. https://doi.org/10.17719/jisr.2018. 2856

van Laar, E., van Deursen, A. J. A. M., van Dijk, J. A. G. M., \& de Haan, J. (2017). The relation between 21st-century skills and digital skills: A systematic literature review. Computers in Human Behavior, 72, 577-588. https://doi.org/10.1016/j.chb.2017.03.010

Vizcaíno-Verdú, A., Contreras-Pulido, P., \& Guzmán-Franco, M.-D. (2019). Reading and informal learning trends on YouTube: The booktuber. Comunicar, 27(59), 95-104. https://doi.org/10.3916/C59-2019-09

Vural, Z. B. A., \& Bat, M. (2010). Yeni Bir İletişim Ortamı Olarak Sosyal Medya: Ege Üniversitesi Illetişim Fakültesine Yönelik Bir Araştırma [Social Media as a New Communication Environment: A Research on Ege University Faculty of Communication]. Journal of Yaşar University, 20(5), 3348-3382.

Weinberg, T. (2009). The new community rules: Marketing on the social web (1st ed). Beijing; Sebastopol, CA: O'Reilly.

Werner, L. A., \& Frank, C. E. (2010). A New Look at Security Education: YouTube as YouTool. 8.

www.wearesocial.com. (2019, April 25). The state of digital in April 2019: All the numbers you need to know. Available at We Are Social website: https://wearesocial.com/blog/2019/ 04/the-state-of-digital-in-april-2019-all-the-numbers-you-need-to-know (Accessed July 13, 2019)

Yeo, M. M. L. (2014). Social media and social networking applications for teaching and learning. European Journal of Science and Mathematics Education, 10.

Yıldırım, A., \& Şimşek, H. (2011). Sosyal bilimlerde nitel araştırma yöntemleri [Qualitative research methods in Social Sciences]. Seçkin yayıncılık.

YouTube. (2019). YouTube Hakkında-YouTube. Available at: https://www.youtube.com/yt/ about/

Correspondence: Aslıhan Saban, Necmettin Erbakan University, Turkey.

E-mail: aslihansaban@gmail.com 